\title{
Using infrared thermography to measure the body surface temperature of crossbred cows and calves in the semi-arid region of Minas Gerais, Brazil
}

\author{
Cinara da Cunha Siqueira Carvalho iD. Ananda Cordeiro de Souza ID . Heberth Christian Ferreira (iD). \\ Vicente Ribeiro Rocha Júnior ID. José Reinaldo Mendes Ruas ID. Maria Dulcinéia da Costa ID. \\ Carla Cristine Fernandes Guimarães ID. Hellén Felicidade Durães iD. Maria Cecília Magalhães Gonçalves iD
}

CCS Carvalho (Corresponding author) - AC Souza - HC

Ferreira - VR Rocha Júnior - JRM Ruas - MD Costa •

CCF Guimarães • HF Durães • MCM Gonçalves

Departamento de Ciências Agrárias, Universidade Estadual de

Montes Claros (UNIMONTES), Janaúba, MG, Brazil.

Received: December 20, 2018 • Revised: February 21, 2019 • Accepted: February 22, 2019

\begin{abstract}
This study aimed to evaluate the body surface temperature of crossbreed cows and calves managed in the semi-arid region of Minas Gerais (Brazil), using the infrared thermography technique. The thermal environment was characterized by daily collections of meteorological variables and subsequent calculation of thermal indices. Body surface temperature (BST) was measured at 6:00, 12:00 and 16:00 hours, at 1.0, 1.5, 2.0 and 4.0 meters distances from the animals to measure the right and left flank temperature and compare with the different information obtained in the literature. The thermal environment was classified as an emergency from 12:00. There was no significative difference between the distances studied, where the body surface temperature of cows and calves was $36.8{ }^{\circ} \mathrm{C}$ and $38.2{ }^{\circ} \mathrm{C}$, respectively. There was significative interaction between the hours and the laterality of the body, where at 7:00 the BST was higher in the left flank due to the more intense ruminal activity and at 16:00 there was no difference in the BST, but in this period the higher BST values were observed due to the thermal environment. It is possible to obtain BST by means of thermographic camera reliably up to a distance of $2.0 \mathrm{~m}$. The thermal environment elevates BST in the afternoon period, but the adaptability of the animals obtained through heterosis does not expose them to the heat stress condition. The microclimate of the shaded environment and in full sun does not interfere with the calves' preference of accommodation.
\end{abstract}

Keywords: ambience, thermographic analysis, dairy cattle, heterosis, shading

\section{Introduction}

Dairy farming in Brazil is the economic base of most small and medium farmers, especially in the state of Minas email: cinarasiqueira@yahoo.com.br

Gerais. However, for these farmers, productivity is still strongly affected by irregular food offer throughout the year, the use of unadapted crosses or low production potential, management actions considered aversive, and climatic factors (Zeferino et al 2017; Diniz et al 2017).

Dairy cattle are animals that respond well when raised in temperate environments, but Brazil is a predominantly tropical country, with high temperatures during the year in most of its territory, which causes heat stress in a way that the use of adapted animals to different climatic conditions is of greater interest (Castro et al 2018; Pereira et al 2018).

In the dairy production context, calves are considered important because they represent a significant portion of future profitability. Thus, it is understood that management, sanity, nutrition, and environment care must be rigorous from birth to weaning to avoid trauma, reduction of immunity and consequently affect milk production in the future (Signoretti 2013).

Evaluating the environmental variations in the breeding system of dairy cows and its calves become great importance in order to verify heat stress conditions and, previously, adopt measures that make the comfortable environment and conducive to the animal productivity maintenance.

In this scenario, the use of infrared thermography allows efficient monitoring of physiological responses in a non-invasive way, identifying possible differences in body surface temperature (Roberto e Souza 2014). The body surface temperature has been a highly analyzed variable due to the ease of obtaining the thermographic images. With this technology, it is possible to verify with greater precision the environmental factors influence, soil temperature effects, hair coat coloration, heat dissipation due to the possibility of 
shading, feed and water intake, and the skin vascularization level.

However, it is found that in the market, the number of marks, models, resolutions, and prices of thermographic cameras is varied, and these factors interfere in the camera's acquisition. Due to these factors, in the scientific works, there is variation in the equipment models used, as well as in the distances adopted during the thermal images registrations due to the resolutions.

Thus, we sought to verify by infrared thermographic records the body surface temperature obtained at different distances from the animal, as well as the thermal environment effects on the laterality of the body of crossbred cows and calves raised at pasture and under climatic conditions of the semi-arid region of Minas Gerais, Brazil.

\section{Materials and Methods}

The experiment was conducted at the Experimental Farm of the Universidade Estadual de Montes Claros (UNIMONTES), Janaúba, Brazil, specifically in the semi-arid region of Minas Gerais state. The experimental area is located at $43^{\circ} 16^{\prime} 18^{\prime \prime} \mathrm{W}$ and $15^{\circ} 49^{\prime} 51^{\prime \prime} \mathrm{S}$, with an average elevation of approximately $540 \mathrm{~m}$. The average rainfall is $870 \mathrm{~mm}$, mean annual temperature of 24 to $28{ }^{\circ} \mathrm{C}$ and the average relative humidity of $65 \%$. The climate type is Aw, characterized tropical rainy and Savannah with dry winter, according to the classification of Köppen-Geiger.

Data collection occurred during the month of October, in which ten F1 Holstein x Zebu cows (average weight of 500 $\mathrm{kg}$ ) in lactation and their six calves $3 / 4$ Holstein $x$ Zebu (average weight of $90 \mathrm{~kg}$ ) were evaluated.

For cows, completely randomized design was used, which followed the factorial scheme $3 \times 2 \times 2$, with three distances (1.0, 1.5 and $2.0 \mathrm{~m})$, two body sides to compare the laterality (right and left flanks) and two milking times (07:00 and 16:00). These collections occurred with the animals contained in the trunk. A second analysis was performed to mensuration the body surface temperature (BST) at $4.0 \mathrm{~m}$ from the animals. The $3 \times 2$ factorial scheme was adopted, being 3 times of day (07:00, 12:00 and 16:00) and 2 body sides (right and left flanks). Both analyzes had 10 replicates. Before the data collection occurs, the distances were tested by evaluators, which could approach the animals safely while they were free to pasture. In this work, the body surface temperature from $4.0 \mathrm{~m}$ distance was registered, thus seeking to prioritize the safety of the evaluators.

For calves, completely randomized design was used in the $3 \times 2 \times 2$ factorial scheme, being three distances (1.0, 1.5 and $2.0 \mathrm{~m}$ ), two sides to laterality comparison (right and left flanks) and two hours (07:00 and 16:00) with 6 replicates. The data collections occurred with the free calves in the calf hutches.
The cows were managed in pasture formed by Uruchloa Brizantha $c v$. Marandú with water ad libitum. During the experiment, the animals had free access to the corral e receiving $3 \mathrm{~kg}$ of concentrated ration (24\% crude protein) after milking. The calves remained in calf hutches at the side of the corral from which they came out only to be fed by cows after milking (07:00 and 16:00). The calves also received sorghum silage or elephant grass in the trough, in addition to concentrated ration. Water was also available ad libitum. The calf hutch $(8.80 \mathrm{~m} \times 5.82 \mathrm{~m})$ had a trapezoidal structure, a wall height of $2.90 \mathrm{~m}$ and the opposite part of 1.37 $\mathrm{m}$. The facility was built with a fiber-cement roof, next to the corral and surrounded by surrounding landscaping. The calf hutch still had an area where the animals had access to the sun with the following measures: 3,60 $\mathrm{m} \times 5,3 \mathrm{~m}$ and 2,9 $\mathrm{m}$ of right foot.

The meteorological variables were measured using two dataloggers sets (model RHT 10, Extech). Each set was composed of two dataloggers, where one was affixed inside a black copper globe to determine the black globe temperature (Tgn, ${ }^{\circ} \mathrm{C}$ ) and the other equipment was positioned near the globe to capture the air temperature $\left(\right.$ Tar, ${ }^{\circ} \mathrm{C}$ ), dew point temperature $\left(\mathrm{Tpo},{ }^{\circ} \mathrm{C}\right)$ and relative humidity $(\mathrm{RH}, \%)$. One set was placed in the pasture where the cows grazed all day and the second set was placed under the roof of the calf hutches (shaded area), at the height of the calves. The dataloggers were programmed to record data every 30 minutes. The wind velocity $(\mathrm{Vv}, \mathrm{m} / \mathrm{s})$ was obtained using the portable digital anemometer (model AD 250, Instrutherm).

The Black Globe-Humidity Index (BGHI) proposed by Buffington et al. (1981) was obtained by Equation 1:

$$
\mathrm{BGHI}=\underset{(\text { Equation } 1)}{\operatorname{Tgn}+0,36 \times \mathrm{Tpo}+41,5}
$$

where Tpo is the dew point temperature $\left({ }^{\circ} \mathrm{C}\right)$ and $\mathrm{Tgn}$ is the black globe temperature $\left({ }^{\circ} \mathrm{C}\right)$.

The radiant heat load (RHL, W.m- ${ }^{2}$ ) was also calculated through Equation 2 (Esmay 1982):

$$
\text { RHL }=s(\text { MRT })^{4}
$$

(Equation 2)

where $\mathrm{s}$ is the Stefan-Boltzmann constant $\left(5,67 \times 10^{-8} \mathrm{~W} \cdot \mathrm{m}^{-2} \mathrm{~K}\right.$ $\left.{ }^{4}\right)$ and the MRT $(\mathrm{K})$ is the mean radiante temperature, which was obtained through Equation 3:

$$
M R T=100 \sqrt[4]{2,51 x \sqrt{\operatorname{Vvx}(\operatorname{Tgn}-\operatorname{Tar})+\left(\frac{\operatorname{Tgn}}{100}\right)^{4}}}
$$

(Equation 3)

where $V v$ is the wind speed $(\mathrm{m} / \mathrm{s}), \operatorname{Tgn}=$ is the black globe temperature $\left({ }^{\circ} \mathrm{C}\right)$ and the Tar is the air temperature $(\mathrm{K})$. 
The body surface temperature $\left(\mathrm{BST},{ }^{\circ} \mathrm{C}\right)$ was obtained with the use of a thermographic camera (model C2, Flir ${ }^{\circledR}$ ) and emissivity of 0.98 . The BST of right and left flanks of the cows was recorded at 1.0, 1.5, 2.0 at 07:00 and 16:00, to confront the different distances adopted in the literature and to verify the ruminal activity effects (Montanholi et al 2008). Records were also made $4.0 \mathrm{~m}$ away at 07:00, 12:00 and 16:00 during the period when the animals were in the pasture. For calves, the BST measures were recorded on the flanks at distances of 1.0, 1.5 and $2.0 \mathrm{~m}$ at 07:00 and 16:00, inside the calf hutches.

By means of on-site observations, an evaluator found at 7:00, 12:00 and 16:00 the place where calves preferred to remain for most of the time, ie in the sun or shade.

The variables were submitted to analysis of variance using the SISVAR ${ }^{\circledR}$ statistical software (Ferreira 2008) and, when the $\mathrm{F}$ test was significative $(P<0.05)$, the means were compared by the Tukey test $(P<0.05)$.

\section{Results and Discussion}

As a way of characterizing the environment in sun and shade, it was verified that the highest mean values $(P<0.05)$ of air temperature, BGHI, and RHL, and the lowest mean values of RH occurred at 12:00 (Table 1). However, it is worth mentioning that, in the pasture, the cows were managed in full sun, where the BGHI (90.7) characterized the environment like "emergency" (BGHI> 84) according to the classification proposed by Buffington et al (1981). Thermal discomfort can be observed even in places where animals are reared (Moreira et al 2017).

Table 1 Mean values of air temperature (Tar), relative humidity (RH), Black Globe-Humidity Index (BGHI) and Radiant Heat Load (RHL) in the sun and shade environment.

\begin{tabular}{cccccccccc}
\hline \multirow{2}{*}{ Time of day } & \multicolumn{2}{c}{ Tar $\left({ }^{\circ} \mathrm{C}\right)$} & \multicolumn{2}{c}{$\mathrm{RH}(\%)$} & \multicolumn{2}{c}{ BGHI } & \multicolumn{2}{c}{ RHL $\left(\mathrm{W} . \mathrm{m}^{2}\right)$} \\
\cline { 2 - 9 } & Sun & Shade & Sun & Shade & Sun & Shade & Sun & Shade \\
\hline $07: 00$ & $24.5^{\mathrm{aC}}$ & $25.0^{\mathrm{aB}}$ & $47.7^{\mathrm{bA}}$ & $54.6^{\mathrm{aA}}$ & $70.0^{\mathrm{bC}}$ & $71.9^{\mathrm{aB}}$ & $384.2^{\mathrm{aB}}$ & $391.8^{\mathrm{aB}}$ \\
$12: 00$ & $39.4^{\mathrm{aA}}$ & $33.1^{\mathrm{bA}}$ & $20.3^{\mathrm{bC}}$ & $32.4^{\mathrm{aB}}$ & $90.7^{\mathrm{aA}}$ & $80.7^{\mathrm{bA}}$ & $561.5^{\mathrm{aA}}$ & $444.8^{\mathrm{bA}}$ \\
$16: 00$ & $32.0^{\mathrm{aB}}$ & $33.3^{\mathrm{aA}}$ & $32.1^{\mathrm{aB}}$ & $33.7^{\mathrm{aB}}$ & $79.0^{\mathrm{bB}}$ & $81.4^{\mathrm{aA}}$ & $503.1^{\mathrm{aC}}$ & $456.9^{\mathrm{bA}}$ \\
\hline $\mathrm{CV}^{1}(\%)$ & 3.8 & & 7.6 & & 1.3 & & 2.3 \\
\hline
\end{tabular}

Means followed by the same letter do not differ statistically from each other: lowercase in the row and upper case in the column (Tukey's test; $P<0.05$ ).

CV: Coefficient of variation

After birth, the calf will need to adapt as quickly as possible to extrauterine life to face the various physiological changes. If the calf is subjected to prolonged heat stress, the chances of developing diseases are increased, raising the morbidity and mortality rates (Signoretti 2013; Cunningham 2004). Barnabé et al (2015), evaluating the use of three roofing types for individual hutches during the summer in the Brazilian Northeast, verified that the air temperature provided by the fiber cement tile was higher $(P<0.05)$ than the other tiles evaluated. The housed animals in shelters with fiber cement roof cover remained above the upper critical temperature between 08:00 and 14:00, as was verified in the present study.

Due to the material used as a constituent of the cover and the right foot, the hutch microclimate presented high mean values higher than that registered in the area without shade $(\mathrm{P}$ $<0.05)$. Although the microclimate provided by the material used in the cover has raised the BGHI, the coverages used in animal production facilities attenuate the external radiant heat load (RHL) on the animals during the critical periods of the day (Cardoso et al 2011). These authors further describe that around 13:00 the RHL reduction can occur between 37 and $40 \%$, depending on the material type used. In present work, it was verified that at 12:00 the cover system reduced the direct solar radiation incidence at $116.7 \mathrm{~W} . \mathrm{m}^{-2}$ and at $16: 00$ at 46.2 W. $\mathrm{m}^{-2}$.

Furtado et al (2003) reported that the RHL values occur as a function of solar radiation, reaching the highest values close to 12:00 when the sun is positioned perpendicular to the terrestrial horizon plane. Façanha et al (2010), evaluating the thermal environment of the rearing system of crossbred Holstein cows in the semi-arid region of Paraiba state (Brazil), found an RHL mean of 702.07 W.m ${ }^{-2}$ in September. In the present study, we found that in October the RHL ranged from $384.7 \mathrm{~W} . \mathrm{m}^{-2}$ to $553.8 \mathrm{~W} . \mathrm{m}^{-2}$ in the sun and from $386.4 \mathrm{~W} . \mathrm{m}^{-2}$ to $465.2 \mathrm{~W} . \mathrm{m}^{-2}$ in the shade, with the mean values was 480.8 $\mathrm{W} . \mathrm{m}^{-2}$ in the sun and $430.0 \mathrm{~W} \cdot \mathrm{m}^{-2}$ in the shade.

There was no significative difference in the body surface temperature of cows and calves between the different distance studied $(P>0.05)$. The BST mean of the cows were $36.8^{\circ} \mathrm{C}$ and the calves were $38.2^{\circ} \mathrm{C}$. In the laterality analysis, it was verified that there was a significative interaction $(P<$ 0.05 ) between the times of day and temperature of the right and left flanks. For cows and calves, we found that BST was higher on the left flank at 07:00, whereas at 16:00 there was no difference $(P>0.05)$. 
The proximity of the left flank to rumen makes this body region an indicator of temperature variations within the rumen, whereas the right flank reflects the body's nucleus temperature (Laue and Petersen 1991; Montanholi et al 2008).

Cows' BST was collected after milking, but before morning milking the cows were kept in grazing until a few moments before being milked and, during this activity, they received concentrate ration in the trough. In the afternoon shift, the animals waited for milking in the pasture, but in idleness. Thus, we verified that before the milking occurred the grazing activity was lower than in the morning shift. We found that the difference $(P<0.05)$ found between BST on the left and right flanks in the morning was due to more intense ruminal activity, whereas in the afternoon there was no significative difference $(P>0.05)$ by virtue of idleness (even receiving the concentrate ration in the trough). In addition, the thermal environment also has a cumulative effect on the hair coat surface temperature of the animals.

Table 2 Mean values of thermographic records of body surface temperature $\left({ }^{\circ} \mathrm{C}\right)$ performed on the left and right sides of the crossbreed cows and calves, according to the times of day.

\begin{tabular}{|c|c|c|c|c|}
\hline \multirow{2}{*}{ Anatomical part } & \multicolumn{2}{|c|}{ Cows } & \multicolumn{2}{|c|}{ Calves } \\
\hline & 07:00 & $16: 00$ & 07:00 & $16: 00$ \\
\hline Right flank & $34.5^{\mathrm{bB}}$ & $38.3^{\mathrm{aA}}$ & $36,3^{\mathrm{bA}}$ & $35,8^{\mathrm{bA}}$ \\
\hline Left flank & $36.5^{\mathrm{aB}}$ & $38.1^{\mathrm{aA}}$ & $38,9^{\mathrm{aB}}$ & $42,0^{\mathrm{aA}}$ \\
\hline $\mathrm{CV}(\%)$ & \multicolumn{2}{|c|}{2.57} & \multicolumn{2}{|c|}{6.10} \\
\hline
\end{tabular}

The animals of the present study had mostly black' skin and epidermis. This characteristic gives the animal the maximum of solar radiation absorption. Although the highest values of Tar, RHL, and BGHI $(P<0.05)$ occurred at 12:00, the hair coat surface can absorb and accumulate heat in the body tissues, so in the afternoon the BST values are higher when compared to the morning period.

When analyzing the heat production, Montanholi et al (2008) observed an increase in body surface temperature after 2 hours of each feeding and, at 15:00, a decrease in body surface temperature in different body regions after milking. Diniz et al (2017), when analyzing body surface temperature, observed that at 15:00, the values were $37.7{ }^{\circ} \mathrm{C}$ and in the morning shift of $35.0^{\circ} \mathrm{C}$. This difference was attributed to the environmental conditions and animal' hair coat surface.

In the thermographic analysis performed four meters away, in order to focus the cows' body and safely for the evaluators, we verified that there was no difference $(P>0.05)$ between the right and left flanks, being the average value of $37.8^{\circ} \mathrm{C}$. Between times of day, the BST was greater at 16:00.

In the area where the calves were accommodated all day, there was free access to the sun and shade. No significative difference $(P>0.05)$ between the hours and between the environment chosen by calves (sun and shade). This indicates that the microclimate provided by the shaded environment and full sun did not interfere with the accommodation preference. From 12:00, when the thermal environment was considered a stressor and when the highest values of BST were recorded, $50 \%$ of the calves chose to remain in the space of the calf without shading.
The area per animal in the calf hutches was $6.4 \mathrm{~m}^{2}$ higher than recommended by Campos (2016), which was from 2.0 to $2.5 \mathrm{~m}^{2}$ per animal. This allowing the animals would have the freedom to choose where to stay inside the calf hutches, both in the sun and in the shade.

According to Leme et al (2005), calves have shadowing behavior more evidenced in the summer when the heat thermal sensation increases. However, when confronted with the thermal conditions verified in this study, it can be inferred that the climate was not a factor that caused $100 \%$ of the calves to seek shade during the spring.

There is little literature that reports the calves' behavior managed in environments with and without shading. However, Moreira et al (2017) report that crossbreed cows (Holstein $\mathrm{x}$ Zebu) perform grazing in the hours of higher air temperature. This is possible because of the resistance and rusticity conferred on crossbreed animals and, probably, expressed since the calves phase.

\section{Conclusions}

It is possible to obtain reliable information on the body surface temperature of cows and calves regardless of the distances at which the thermographic records were made. Although the thermal environment in the semiarid state of Minas Gerais during the spring period is considered "emergency", crossbred cows and calves did not express thermal discomfort, since body surface temperature was within the reference values and part of the calves have chosen to stay in the sun at the hottest times. However, further studies 
are needed to determine whether calves' ruminal activity interferes in the body surface temperature.

\section{Acknowledgements}

The present work was carried out with the support of the Coordenação de Aperfeiçoamento de Pessoal de Nível Superior (CAPES; financing code 001); Fundação de Amparo à Pesquisa do Estado de Minas Gerais (FAPEMIG), Conselho Nacional de Desenvolvimento Científico e Tecnológico (CNPq) and Universidade Estadual de Montes Claros.

\section{References}

Barnabé MCJ, Héliton P, Almeida GLPDE, Guiselini, C, Jacob AL (2015) Conforto térmico e desempenho de bezerras Girolando alojadas em abrigos individuais com diferentes coberturas. Revista Brasileira de Engenharia Agrícola e Ambiental 19:481-488.

Buffington DE, Collazo-Arocho A, Canton GH, Pitt D, Thatcher WW, Collier RJ (1981) Black globe humidity index (BGHI) as a comfort equation for dairy cows. Transactions ASAE 24:711-714.

Campos AT (2016) Importância das instalações. EMBRAPA. http://www.agencia.cnptia.embrapa.br/Agencia8/AG01/arvore/AG0 1_291_217200392412.html. Acesso em: 19 de julho de 2018.

Cardoso AS, Baêta FC, Tinôco IFF, Cardoso VAS (2011) Coberturas com materiais alternativos de instalações de produção animal com vistas ao conforto térmico. Revista Engenharia na Agricultura 19:404-421

Castro ALO, Carvalho CCS, Ruas JRM, Pereira KCB, Menezes GCC, Costa MD (2018) Parâmetros fisiológicos de vacas F1 Holandês x Zebu criadas em ambientes com e sem sombreamento. Arquivo Brasileiro de Medicina Veterinária e Zootecnia 70:722-730.

Cunningham JG (2004) Termorregulação In: Tratado de fisiologia veterinária 3.ed. Rio de Janeiro: Guanabara Koogan.

Diniz TA, Carvalho CCS, Ferreira HC, Castro ALO, Pereira KCB, Goncalves MCM, Soares TE, Menezes JC (2017) Vacas F1 Holandês $\mathrm{x}$ Zebu no terço final de gestação apresentam adaptação fisiológica quando criadas no ambiente semiárido. Revista de Ciências Agroveterinárias 16:70-75.

Esmay ML (1982) Principles of animal environment. Westport: Avi, 325p.
Façanha DAE, Silva RG, Maia ASC, Guilhermino MM, Vasconcelos AM (2010) Variação anual de características morfológicas e da temperatura de superfície do pelame de vacas da raça Holandesa em ambiente semiárido. Revista Brasileira de Zootecnia 39:837-844.

Ferreira DF (2008) Programa Sisvar versão 5.1. Programa de análises estatísticas. Lavras: DEX/UFLA.

Furtado DA, Azevedo PV, Tinôco IFF (2003) Análise do Conforto térmico em galpões avícolas com diferentes sistemas de acondicionamento. Revista Brasileira de Engenharia Agrícola e Ambiental 7:559-564.

Laue HJ, Petersen U (1991) Relations between temperature changes in the rumen and roughage intake of dairy cows. Zuechtungskunde 63:282-293.

Leme T, Pires M, Verneque RDS, Alvim MJ, Aroeira LJM (2005) Comportamento de vacas mestiças Holandês x Zebu, em pastagem de Brachiaria decumbens em sistema silvipastoril. Ciência e Agrotecnologia 29:668-675.

Montanholi YR, Odongo NE, Swanson KC, Schenkel FS, McBride BW, Miller SP (2008) Application of infrared thermography as an indicator of heat and methane production and its use in the study of skin temperature in response to physiological events in dairy cattle (Bos taurus). Journal of Thermal Biology 33:469-475.

Moreira SJM, Carvalho CCS, Santos LV, Ruas JRM, Andrade Júnior IO, Aiura ALO, Gonçalves, AM (2017) Respostas fisiológicas e adaptabilidade de vacas $3 / 4$ Holandês $x$ Zebu ao clima do semiárido. Boletim da Indústria Animal 74:162-168.

Pereira KCB, Carvalho CCS, Ruas JRM, Castro ALO, Menezes GCC, Costa MD (2018) Effect of the climatic environment on ingestive behavior of F1 Holstein x Zebu cows. Revista Brasileira de Saúde e Produção Animal 19:207-215.

Roberto JVB, Souza BB (2014) Utilização da termografia de infravermelho na medicina veterinária e na produção animal. Journal of Animal Behaviour and Biometeorology 2:73-84.

Signoretti RD (2013) Práticas de Manejo para Correta Criação de Bezerras Leiteiras. Consultoria Avançada em Pecuária. http://www. coanconsultoria. com. br/images/Artigos/Pr\% C3\% A1 ticas\% 20na\% $20 \mathrm{Cria} \% \quad \mathrm{C} 3 \% \quad \mathrm{~A} 7 \% \quad \mathrm{C} 3 \% \quad \mathrm{~A} 3 \mathrm{o} \% \quad 20 \mathrm{de} \% \quad$ 20Bezerras\% 20Leiteiras>pdf. Acesso em: 01 de dezembro de 2018.

Zeferino ES, Carvalho CCS, Rocha LAC, Ruas JRM, Reis ST (2017) Qualidade do leite produzido no semiárido de Minas Gerais. Revista de Ciências Agroveterinárias 16:54-60. 